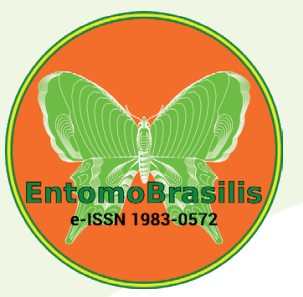

\title{
Strains of Spodoptera frugiperda (J.E.Smith) (Noctuidae) in the states of Paraná and São Paulo, Brazil
}

\author{
Francielly Silveira Richardt ${ }^{1}$, Adriana Micheli², Daniele Tasior ${ }^{2}$, \\ Elderson Ruthes ${ }^{2}$ \& Luís Amilton Foerster ${ }^{1}$
}

1. Universidade Federal do Paraná. 2. Fundação $A B C$.

\section{EntomoBrasilis 13: e0854 (2020)}

\author{
Edited by: \\ William Costa Rodrigues \\ Article History: \\ Received: 21.v.2019 \\ Accepted: 27.xii.2019 \\ Published: 17.ii.2020 \\ $\bowtie$ Corresponding author: \\ Francielly Silveira Richardt \\ ७ franrichardt@gmail.com \\ (1) orcid.org/0000-0003-3405-208X \\ Funding agencies: \\ $\leftrightarrow$ Without funding declared
}

\begin{abstract}
Two strains of Spodoptera frugiperda (J.E. Smith) were first described in the United States; in Brazil, in the states of Rio Grande do Sul, Mato Grosso, and western Paraná they have also been reported. This study was aimed at identifying these strains in Norte Pioneiro and Campos Gerais, in the states of Paraná and southwestern São Paulo. Larvae of S. frugiperda were collected in the cities of Ponta Grossa, Tibagi, Arapoti, and Wenceslau Braz in Paraná, and in the city of Itaberá, in São Paulo. PCR-RFLP genotyping of the COI gene was carried out using sixty-six specimens. Based on their electrophoretic pattern, 51 individuals were identified as corn strain, five as rice strain, and 10 as hybrids (Rice in Mspl and Maize in Sacl). Our findings indicate that both S. frugiperda strains are present the study areas.
\end{abstract}

Keywords: COI; Hybrids; Mspl; RFLP; Sacl.
Tim he fall armyworm, Spodoptera frugiperda (J.E. Smith) is widely distributed in the western hemisphere, occurring from central-southern Canada to southern Argentina (Pogue 2002). Recently, this pest has become a new invasive species in West and Central Africa, where it was first recorded in early 2016 (Goengen et al. 2016; Jeger et al. 2017).

Two strains of S. frugiperda were first described in the United States (PASHLEY 1986), and since then they have also been reported in Mexico (Rosas-García et al. 2016), Colombia (CANOCAlle et al. 2015), Argentina (Murúa et al. 2015), Paraguay (JuÁrez et al. 2012), and Africa (Cock et al. 2017).

In Brazil, studies have confirmed the presence of these two S. frugiperda strains especially in Rio Grande do Sul (BusATO et al. 2002, 2004, 2005; MACHADO et al. 2008), but also in Mato Grosso (Campo Verde and Primavera do Leste) and Paraná (Palotina) (NAGOSHI et al. 2007).

Several studies have also reported distinct susceptibilities of S. frugiperda strains to chemical pesticides (BusATO et al. 2006; Hay-Roe et al. 2011; Ríos-Díez \& Saldamando-Benjumea 2011) and Bt plants (Ríos-Díez et al. 2012). In order to account for these differences in the control of this pest, our objective was to identify these strains in different crops in areas of Norte Pioneiro and Campos Gerais, in Paraná and southwestern São Paulo.

MATERIAL AND METHODS
The study was carried out at the Laboratory of Entomology and Phytopathology (LabEF) at the ABC Foundation Agricultural Research and Development, in the city of Castro, Paraná. Control specimens of the corn and rice strains were obtained from the Federal University of Mato Grosso (UFMT) and the United States Department of Agriculture - Agricultural Research Service (USDA-ARS), respectively.

Larvae of S. frugiperda were collected in the cites of Ponta Grossa, Tibagi, Arapoti, and Wenceslau Braz in Paraná, and in the cities of Itaberá, in São Paulo. Individuals were maintained under laboratory conditions in a climate room at a temperature of $25 \pm 1^{\circ} \mathrm{C}, 70 \pm 10 \%$ relative humidity, and 14-h photoperiod, and fed an artificial diet (HofFMANN-CAMPO et al. 1985) until reaching the pupal stage, when they were transferred to a freezer $\left(-20^{\circ} \mathrm{C}\right)$ for later DNA extraction.

Spodoptera frugiperda DNA was extracted using the CTAB method with modifications, followed by PCR-RFLP of the mitochondrial gene COI for insect genotyping (CANO-CALLE et al. 2015). The amplification was performed in a $25 \mu \mathrm{L}$ reaction mix containing $2.5 \mu \mathrm{L}$ of $10 \mathrm{X}$ reaction buffer, $0.75 \mu \mathrm{L}$ of $50 \mathrm{mM}$ $\mathrm{MgCl} 2,0.5 \mu \mathrm{L}$ of $10 \mathrm{mM}$ dNTPs, $1.0 \mu \mathrm{L}$ of the forward primer JM76 (5' GAGCTGAATTAGG(G/A)ACTCCAGG 3'), $0.5 \mu \mathrm{L}(5 \mathrm{U} / \mu \mathrm{L})$ of Taq DNA polymerase, $13.75 \mu \mathrm{L}$ of sterile ultrapure water, and $5.0 \mu \mathrm{L}$ of DNA (10 $\mathrm{ng} / \mu \mathrm{L})$. The thermocycling conditions were as follows: the first cycle started with a temperature of $94^{\circ} \mathrm{C}$ for $3 \mathrm{~min}$, followed by 30 cycles at $94^{\circ} \mathrm{C}$ for $1 \mathrm{~min}, 62^{\circ}$ $\mathrm{C}$ for $1 \mathrm{~min}$, and $72^{\circ} \mathrm{C}$ for $1 \mathrm{~min}$, and a final extension cycle 
at $72^{\circ} \mathrm{C}$ for $10 \mathrm{~min}$. Digestion was then carried out with the restriction enzymes $\mathrm{Mspl}$ and Sacl. For each enzyme, 300 ng of PCR product were transferred to new tubes, $2 \mu \mathrm{L}$ of 10x Buffer (Invitrogen) and $30 \mu \mathrm{L}$ of sterile ultrapure water were added to the solution, followed by 10 units of Mspl $(0.5$ $\mu \mathrm{L})$ or 10 units of Sacl $(0.5 \mu \mathrm{L})$, and incubated at $37^{\circ} \mathrm{C}$ for 2 h. Samples were run on a $2 \%$ agarose gel before and after digestion with restriction enzymes.

The digestion with the restriction enzyme Mspl produces a band of approximately 569 bp that characterizes the rice strain, while in the corn strain, two fragments of approximately 497 and 72 bp are observed (NAGOSHI \& Meagher 2003a). After digestion with the enzyme Sacl, two fragments of approximately $500 \mathrm{bp}$ and $69 \mathrm{bp}$ are present in the rice strain, while only a fragment of approximately 569 bp is observed in the corn strain (NAGOSHI et al. 2006).

\section{RESULTS AND DISCUSSION}

Sixty-six specimens of $S$. frugiperda collected in the study areas and 27 control specimens of the corn and rice strains were genotyped. The electrophoretic patterns found for each strain were similar to those reported by NAGOSHI \& MEAGHER (2003a, 2003b) and NAGOSH et al. (2006). Fifty-one individuals were identified as corn strain, five as rice strain, and 10 as hybrids (Rice in Mspl and Corn in Sacl) (Figure 1).

The presence of hybrids has been reported in different studies (Nagoshi \& Meagher 2003a, 2003b; VÉlEZ-Arango et al. 2008, Salinas-Hernandez \& Saldamando-Benjumea 2011) based on RFLP markers of the Mspl enzyme and PCR of the FR sequence. Saldamando \& Vélez-Arango (2010) described two types of hybrids: individuals characterized by fragments produced by the digestion with the Mspl enzyme and amplification with FR primers (referred to as hybrids $+/+$ ) and individuals distinguished by the absence of fragments produced with the Mspl enzyme or amplification products with FR primers (referred to as hybrids - / -).

CAno-Calle et al. (2015) reported that hybrids were also identified with Sacl; however, this restriction enzyme was only used when the FR fragment was difficult to amplify in the sample.

Hybrids may be the product of interstrain matings, indicating the occurrence of gene flow in the study region. NAGOSHI \& Meagher (2003a) suggested that hybrids result from the unidirectional mating between rice-strain females and cornstrain males, since mating between corn-strain females and rice-strain males was not observed under laboratory conditions. In contrast, Prowel et al. (2004) found evidence of bi-directional breeding in nature, with $54 \%$ of hybrids as the offspring of rice-strain females and corn-strain males and $46 \%$ of reciprocal mating.

Rice-strain individuals are commonly found in habitats occupied by corn-strain populations (Prowell et al. 2004), indicating that they use the corn habitat more often than the opposite, and consequently, hybrids are mostly found in corn fields. Prowell et al. (2004) pointed out that $62 \%$ of hybrids in their study were collected in corn fields. Similarly, SaLDAMANDO \& VÉLEZ-ARANGo (2010) obtained the highest percentage (41\%) of hybrids in the corn habitat. In the present study, most of the hybrids were found in a single egg cluster on wheat, therefore it cannot be inferred that most of them were found in wheat, as this crop was not sampled as the corn habitat.

Our study did not examine the habitats used by the rice strain described in the literature; however, rice-strain individuals were collected in the corn-strain habitat. PROWELL et al. (2004) reported that only $2 \%$ of the individuals collected in the rice habitat were identified as corn strain, while $18 \%$ of individuals collected in the corn habitat were assigned as rice strain. On the other hand, of the two populations collected in black oat, the corn strain predominated.

Both S. frugiperda strains were found in the study areas and the occurrence of hybrids indicates the existence of gene flow between strains. Despite the presence of rice-strain individuals, most specimens were identified as corn strain, which predominates in the region.

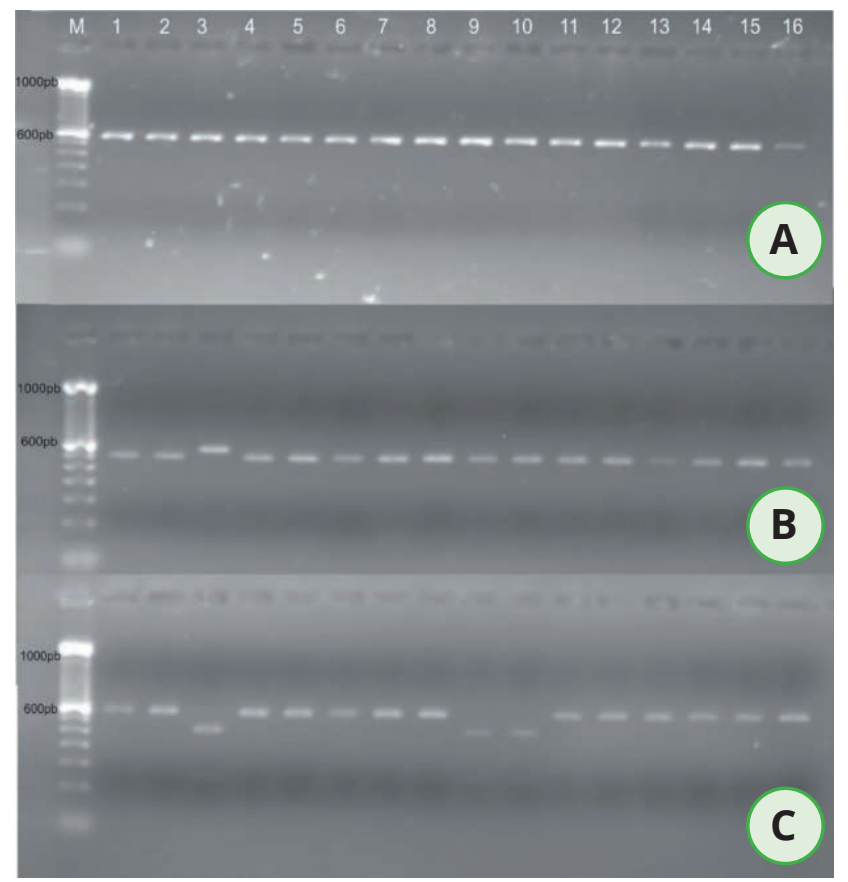

Figure 1. A - Undigested PCR-RFLP product. B - Digestion with the restriction enzyme Mspl. C - Digestion with the restriction enzyme Sacl. Individual 3 assigned as rice strain, individuals 9 and 10 designated as hybrids, and the remainder identified as corn strain. M- Molecular marker (100pb). 2\% agarose gel.

\section{ACKNOWLEDGMENTS}

The authors thank Jessica Cocco (UFPR) and Rob Meagher (United States Department of Agriculture - Agricultural Research Service) for providing specimens, the Laboratory of Entomology and Phytopathology (LabEF) at the $A B C$ Foundation - Agricultural Research and Development, where the study was conducted, and the Coordination of Improvement of Higher Education Personnel (CAPES) for the fellowship granted for the development of this research.

\section{REFERENCES}

Busato GR, AD Grützmacher, MS Garcia, FP Giolo \& AF. Martins, 2002. Consumo e utilização de alimento por Spodoptera frugiperda (JE Smith) (Lepidoptera: Noctuidae) originária de diferentes regiões do Rio Grande do Sul, das culturas do milho e do arroz irrigado. Neotropical Entomology, 31: 525-529. DOI: https://doi.org/10.1590/ S1519-566X2002000400003

Busato GR, AD Grützmacher, AC de Oliveira, EA Vieira, PD Zimmer, MM Kopp\& JM Bandeira, Taís R. Magalhães, 2004. Análise da estrutura e diversidade molecular de populações de Spodoptera frugiperda (JE Smith) (Lepidoptera: Noctuidae) associadas às culturas de milho e arroz no Rio Grande do Sul. Neotropical Entomology, 33 :709-716. DOI: https://doi.org/10.1590/S1519$566 \times 2004000600008$

Busato GR, AD Grützmacher, MS Garcia, FP Giolo, MJ Zotti \& GJ Stefanello Júnior, 2005. Biologia comparada de populações de Spodoptera frugiperda (JE Smith) 
(Lepidoptera: Noctuidae) em folhas de milho e arroz. Neotropical Entomology, 34: 743-750. DOI: https://doi.org/10.1590/S1519-566X2005000500005

Busato GR, AD Grützmacher, MS Garcia, MJ Zotti, SD Nörnberg, TR Magalhães \& JB Magalhães, 2006. Susceptibilidade de lagartas dos biótipos milho e arroz de Spodoptera frugiperda (JE Smith, 1797) (Lepidoptera: Noctuidae) a inseticidas com diferentes modos de ação. Ciência Rural, 36: 15-20. DOI: https://doi.org/10.1590/ S0103-84782006000100003

Cano-Calle D, RE Arango-Isaza \& CI Saldamando-Benjumea, 2015. Molecular identification of Spodoptera frugiperda (Lepidoptera: Noctuidae) corn and rice strains in Colombia by using a PCR-RFLP of the mitochondrial gene cytochrome oxydase I (COI) and a PCR of the gene FR (for rice). Annals of the Entomological Society of America, 108: 172-180. DOI: https://doi.org/10.1093/aesa/sav001

Cock MJW, PK Beseh, AG Buddie, G Cafá \& J Crozier, 2017. Molecular methods to detect Spodoptera frugiperda in Ghana, and implications for monitoring the spread of invasive species in developing countries. Scientific Reports, 7: 4103. DOI: https://doi.org/10.1038/s41598017-04238-y

Goergen G, PL Kumar, SB Sankung, A Togola \& M Tamò, 2016. First report of outbreaks of the fall armyworm Spodoptera frugiperda (JE Smith) (Lepidoptera, Noctuidae), a new alien invasive pest in West and Central Africa. PLoS ONE 11(10): e0165632. DOI: https://doi.org/10.1371/journal. pone.0165632

Hay-Roe MM, RL Meagher \& RN Nagoshi, 2011. Effects of cyanogenic plants on fitness in two host strains of the fall armyworm (Spodoptera frugiperda). Journal of Chemical Ecology, 37: 1314-1322. DOI: https://doi.org/10.1007/ s10886-011-0049-7

Hoffmann-Campo CB, EB De Oliveira \& F Moscardi, 1985. Criação massal da lagarta da soja (Anticarsia gemmatalis). Embrapa Soja-Documentos (EMBRAPA-CNPSo. Documentos, 10, 23 p.

Jeger M, C Bragard, D Caffier, T Candresse, El Chatzivassiliou, K Dehnen-Schmutz, G Gilioli, J-C Gregoire, JAJ Miret, MN Navarro, B Niere, S Parnell, R Potting, T Rafoss, V Rossi, G Urek, A Van Bruggen, W Van der Werf, J West, S Winter, C Gardi, M Aukhojee \& A MacLeod, 2017. Pest categorisation of Spodoptera frugiperda. EFSA Journal, 15: 32. DOI: https://doi.org/10.2903/j.efsa.2017.4927

Juárez ML, MG Murúa, MG García, M Ontivero, MT Vera, JC Vilardi, AT Groot, AP Castagnaro, G Gastaminza \& E Willink, 2012. Host association of Spodoptera frugiperda (Lepidoptera: Noctuidae) corn and rice strains in Argentina, Brazil, and Paraguay. Journal of Economic Entomology, 105: 573-582. DOI: https://doi.org/10.1603/ EC11184

Machado V, M Wunder, VD Baldissera, JV Oliveira, LM Fiúza \& RN Nagoshi, 2008. Molecular characterization of host strains of Spodoptera frugiperda (Lepidoptera: Noctuidae) in Southern Brazil. Annals of the Entomological Society of America, 101:619-626. DOI: https://doi.org/10.1603/00138746(2008)101[619:mcohso]2.0.co;2

Murúa MG, RN Nagoshi, DA dos Santos, MM Hay-Roe, RL Meagher \& JC Vilardi, 2015. Demonstration Using Field Collections that Argentina Fall Armyworm Populations Exhibit Strain-specific Host Plant Preferences. Journal of Economic Entomology, 108: 2305-2315. DOI: https://doi.org/10.1093/jee/tov203

Nagoshi RN \& RL Meagher, 2003a. FR tandem-repeat sequence in fall armyworm (Lepidoptera: Noctuidae) host strains. Annals of the Entomological Society of America, 96: 329-335. DOI: https://doi.org/10.1603/00138746(2003)096[0329:ftsifa]2.0.co;2
Nagoshi RN \& RL Meagher, 2003b. Fall armyworm FR sequences map to sex chromosomes and their distribution in the wild indicate limitations in interstrain mating. Insect Molecular Biology, 12: 453-458. DOI: https://doi.org/10.1046/j.1365-2583.2003.00429.x

Nagoshi RN, RL Meagher, JJ Adamczyk, SK Braman, RL Brandenburg \& G Nuessly. 2006. New restriction fragment length polymorphisms in the cytochrome oxidase I gene facilitate host strain identification of fall armyworm (Lepidoptera: Noctuidae) populations in the southeastern United States. Journal of Economic Entomology, 99: 671677. DOI: https://doi.org/10.1093/jee/99.3.671

Nagoshi RN, JJ Adamczyk, RL Meagher, J Gore \& R Jackson, 2007. Using stable isotope analysis to examine fall armyworm (Lepidoptera: Noctuidae) host strains in a cotton habitat. Journal of Economic Entomology, 100: 1569-1576. DOI: https://doi.org/10.1093/jee/100.5.1569

Pashley DP, 1986. Host-associated genetic differentiation in fall armyworm (Lepidoptera: Noctuidae): a sibling species complex?. Annals of the Entomological Society of America, 79: 898-904. DOI: https://doi.org/10.1093/aesa/79.6.898

Pogue GM, 2002. A world revision of the genus Spodoptera Guenée (Lepidoptera: Noctuidae). Memoirs of the American Entomological Society, 43: 1-202.

Prowell DP, M Mcmichael \& JF Silvain, 2004. Multilocus genetic analysis of host use, introgression, and speciation in host strains of fall armyworm (Lepidoptera: Noctuidae). Annals of the Entomological Society of America, 97: 1034-1044. DOI: https://doi.org/10.1603/00138746(2004)097[1034:mgaohu]2.0.co;2

Ríos-Díez JD \& CI Saldamando-Benjumea, 2011. Susceptibility of Spodoptera frugiperda (Lepidoptera: Noctuidae) strains from central Colombia to two insecticides, methomyl and lambda-cyhalothrin: a study of the genetic basis of resistance. Journal of Economic Entomology, 104: 16981705. DOI: https://doi.org/10.1603/EC11079

Ríos-Díez JD, B Siegfried \& Cl Saldamando-Benjumea, 2012. Susceptibility of Spodoptera frugiperda (Lepidoptera: Noctuidae) strains from central Colombia to Cry1 Ab and Cry1Ac entotoxins of Bacillus thuringiensis. Southwestern Entomologist, 37: 281-293. DOI: https://doi.org/10.3958/059.037.0304

Rosas-García NM, V Herrera-Mayorga, G Rivera, M MirelesMartínez, FAP Sánchez, JM Villegas-Mendoza, 2016. Identificación de Biotipos de Spodoptera frugiperda Provenientes de Plantas Hospederas de Maíz en Diferentes Regiones de México. Southwestern Entomologist, 41: 761-770. DOI: https://doi.org/10.3958/059.041.0318

Saldamando Cl \& AM Vélez-Arango, 2010. Host plant association and genetic differentiation of corn and rice strains of Sodoptera frugiperda Smith (Lepidoptera: Noctuidae) in Colombia. Neotropical Entomology, 39: 921-929. DOI: https://doi.org/10.1590/S1519$566 \times 2010000600012$

Salinas-Hernandez H \& Cl Saldamando-Benjumea, 2011. Haplotype identification within Spodoptera frugiperda (JE Smith) (Lepidoptera: Noctuidae) corn and rice strains from Colombia. Neotropical Entomology, 40: 421-430. DOI: https://doi.org/10.1590/S1519-566X2011000400002

Vélez-Arango ANA, RE Arango I, D Villanueva M, E Aguilera G \& Cl Saldamando B, Clara Inés, 2008. Identificación de biotipos de Spodoptera frugiperda (Lepidoptera: Noctuidae) mediante marcadores mitocondriales y nucleares. Revista Colombiana de Entomologia, 34: 145150. 
Richardt, FS, A Micheli, D Tasior, E Ruthes \& LA Foerster, 2020. Strains of Spodoptera frugiperda (J.E.Smith) (Noctuidae) in the states of Paraná and São Paulo, Brazil. EntomoBrasilis, 13: e0854.

Available on: doi: 10.12741/ebrasilis.v13.e0854

\section{(c) (i) (2) (2) \\ BY NC SA}
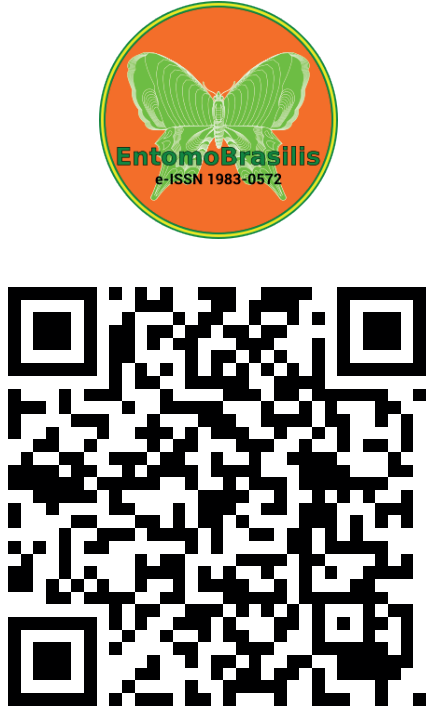